\title{
Money Supply, Inflation and Economic Growth in China: An ARDL Bounds Testing Approach
}

\author{
Cheng-Wen Lee ${ }^{1}$ and Hao-Yuan Yu ${ }^{2}$
}

\begin{abstract}
The empirical analysis applies the autoregressive distributed lag bounds testing approach to investigate the relationship between money supply, inflation and economic growth in China with the time series data from 1980 to 2018, estimate the cointegration of monetary and economic growth in long-run relationship and uses vector error correction model to determine the short-run adjustment between the variables. The research showed that the increase in national income met people's demand for goods and eased inflationary pressures. The results support the view of monetarism and help the government formulate economic policies in a prudent manner to control inflation in China.
\end{abstract}

JEL classification numbers: A10, E52, P44

Keywords: ARDL bounds test, Long-Run, Monetary Neutrality.

${ }^{1}$ Department of International Business, Chung Yuan Christian University, Taoyuan City, Taiwan.

${ }^{2}$ College of Business, Chung Yuan Christian University, Taoyuan City, Taiwan.

Article Info: Received: October 17, 2020. Revised: November 4, 2020.

Published online: November 6, 2020. 


\section{Introduction}

This report attempt to analyze the relationship between money supply, inflation and economic growth. Using ARDL bounds test (Pesaran and Shin, 2001) for such advantage: it performs better to small samples compared to alternative multivariate cointegration procedures; it does not require the restrictive assumption that all series are integrated of the same order, allowing for the inclusion of both $\mathrm{I}(1)$ and $\mathrm{I}(0)$ (but not I(2)) time series in a long-run relationship. And the results could estimate both the short-run dynamic adjustment and the long-run dynamic relationship if cointegration exist.

\section{Data}

All the data have been the time series data from 1980 to 2018 of China, from World Development Indicators. All the variables are followed: M (MONEY -Broad money growth), Y(OUTPUT -GDP growth),P(Inflation, GDP deflator), $\pi$ (Real interest rate).

\section{Methodology}

ARDL model as follows :

$$
\begin{aligned}
& \Delta \mathrm{P}_{t}=\alpha_{0}+\sum_{i=1}^{m} \alpha_{1 i} \Delta \mathrm{P}_{\mathrm{t}-\mathrm{i}}+\sum_{i=0}^{n} \alpha_{2 i} \Delta \mathrm{M}_{\mathrm{t}-\mathrm{i}}+\sum_{i=0}^{n} \alpha_{3 i} \Delta \ln \mathrm{Y}_{\mathrm{t}-\mathrm{i}}+\sum_{i=0}^{n} \alpha_{4 i} \Delta \pi_{\mathrm{t}-\mathrm{i}} \\
& +\theta_{1} \mathrm{P}_{t-1}+\theta_{2} \mathrm{M}_{t-1}+\theta_{3} Y_{t-1}+\theta_{4} \pi_{t-1}+\mu_{t}
\end{aligned}
$$

Where M--BROAD MONEY GROWTH (ANNUAL \%)

Y-- GDP GROWTH (ANNUAL \%)

P--INFLATION, GDP DEFLATOR (ANNUAL \%)

$\pi$--REAL INTEREST RATE (\%)

In the ARDL model, the bounds test is adopted to determine whether there is a longrun equilibrium between the variables, namely whether the cointegration relationship exists.

In the equation, $\alpha_{1 \mathrm{i}}, \alpha_{2 \mathrm{i}}, \alpha_{3 \mathrm{i}}, \alpha_{4 \mathrm{i}}$ represent the short-run dynamic relationship and $\theta_{1}$, $\theta_{2}, \theta_{3}, \theta_{4}$ denote the long-run dynamic relationship.

The bounds test is based on the joint significance of $\mathrm{F}$ statistic and the Chi-square statistic of Wald test, the hypothesis to examine whether there exists cointegration between the variables is expressed as follows:

$$
\begin{array}{ll}
\mathrm{H}_{0}: & \theta_{1}=\theta_{2}=\theta_{3}=\theta_{4}=0 \quad \text { (no cointegrat ion) } \\
\mathrm{H}_{1}: \quad \theta_{1} \neq \theta_{2} \neq \theta_{3} \neq \theta_{4} \neq 0 \quad \text { (cointegrat ion) }
\end{array}
$$

If the calculated $\mathrm{F}$ statistic falls above the upper critical value, the null of no cointegration hypothesis is rejected. If the calculated $\mathrm{F}$ statistic falls below the lower 
critical value, we fail to reject the null of no cointegration hypothesis, which means that there is no cointegration between the variables. While if the calculated $F$ statistic falls inside the upper and lower critical bounds, it cannot be determined whether the cointegration exists between the variables .

The long-run relation between dependent and independent variables is shown by the following equation:

$$
\mathrm{P}_{t}=\gamma_{0}+\gamma_{1} \mathrm{M}_{t}+\gamma_{2} Y_{t}+\gamma_{3} \pi_{t}+\varepsilon_{t}
$$

If it is confirmed that cointegration exists between the variables, an error correction mechanism (ECM) would be:

$$
\Delta \mathrm{P}_{t}=\beta_{0}+\sum_{i=1}^{m} \beta_{1 i} \Delta \mathrm{P}_{\mathrm{t}-\mathrm{i}}+\sum_{i=0}^{n} \beta_{2 i} \Delta \mathrm{M}_{\mathrm{t}-\mathrm{i}}+\sum_{i=0}^{n} \beta_{3 i} \Delta \mathrm{Y}_{\mathrm{t}-\mathrm{i}}+\sum_{i=0}^{n} \beta_{4 i} \Delta \mathrm{l} \pi_{\mathrm{t}-\mathrm{i}}+\lambda E C M_{t-1}+v_{t}
$$

Where $\mathrm{ECM}_{t-i}$ is the error correction term and $\lambda$ is the coefficient of the error correction term which shows the speed of adjustment of the variables to equilibrium in long-run.

\section{Results}

\subsection{Stationary test and optimal lag length}

\subsubsection{Test of Stationarity}

Augmented Dickey-Fuller (ADF) unit root test is used to ensure that the time series data possess the property of stationarity.

Table 1: Unit root test

\begin{tabular}{|c|c|c|c|c|c|c|}
\hline Variable & \multirow{2}{*}{ C.T.K $)$} & ADF & \multicolumn{3}{|c|}{ Test critical values } & \multirow{2}{*}{ Stationarity } \\
\cline { 4 - 6 } & & t-Statistic & $\mathbf{1 \%}$ & $\mathbf{5 \%}$ & $\mathbf{1 0 \%}$ & \\
\hline $\mathrm{M}$ & $\mathrm{C} .0 .0$ & -2.105784 & -3.615588 & -2.941145 & -2.609066 & \\
\hline$\Delta \mathrm{M}$ & 0.0 .0 & -6.654945 & -3.621023 & -2.943427 & -2.610263 & $* * *$ \\
\hline $\mathrm{Y}$ & $\mathrm{C} .0 .1$ & -4.275431 & -3.621023 & -2.943427 & -2.610263 & $* * *$ \\
\hline $\mathrm{P}$ & $\mathrm{C} .0 .1$ & -3.214270 & -3.621023 & -2.943427 & -2.610263 & $* *$ \\
\hline$\pi$ & 0.0 .0 & -2.992245 & -2.627238 & -1.949856 & -1.611469 & $* * *$ \\
\hline
\end{tabular}

All the variable are stationary except the broad money growth, but would be stationary after first difference. 

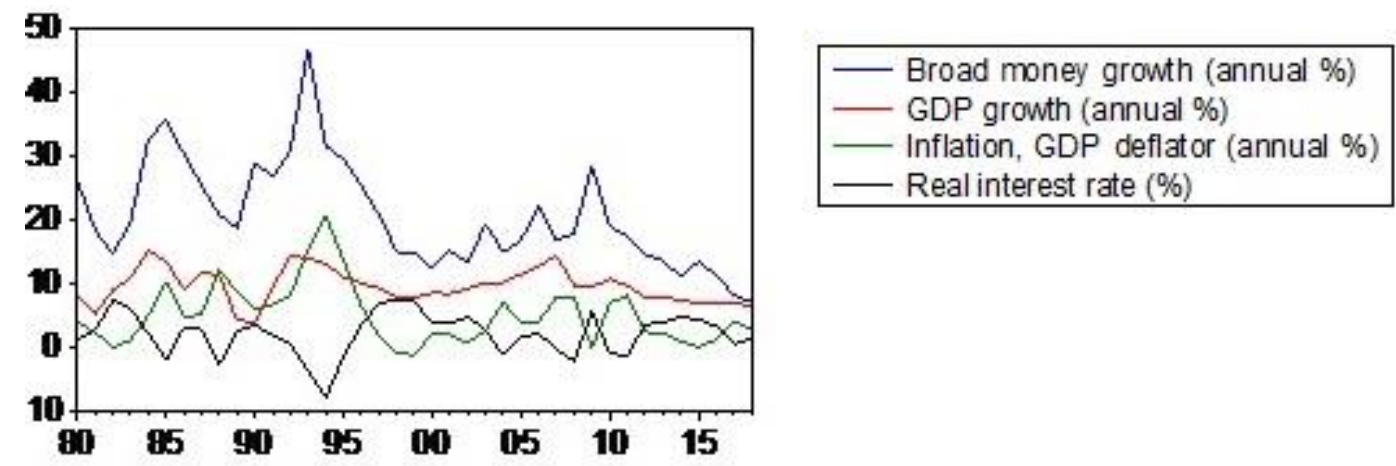

Figure 1

Using ADF test, Y,P, $\pi$ are stationary, and only $\Delta \mathrm{M}$ is I(1), ARDL bounds test is suitable because it does not require the restrictive assumption that all series are integrated of the same order, thus allowing for the inclusion of both $\mathrm{I}(1)$ and $\mathrm{I}(0)$.

\subsection{ARDL cointegration test}

The selection of the optimal ARDL specifications is selected based on the Akaike information criterion (AIC) which is asymptotically consistent for the lag length and is based on a general-to-specific approach, starting with $\max p=\max q=4$ and dropping all the insignificant lags using a 5\% decision rule.

Table 2

\begin{tabular}{|c|c|c|c|c|c|c|c|}
\hline \multicolumn{2}{|c|}{ Variable } & \multicolumn{3}{|c|}{ ARDL } & $\begin{array}{c}\text { F-Bounds } \\
\text { Test } \\
\text { F-Statistic }\end{array}$ & \multicolumn{2}{|c|}{$\begin{array}{l}\text { Cointegration } \\
\text { (Signif) }\end{array}$} \\
\hline & $\mathrm{P}$ & & $\mathrm{L}(4,4$ & ,4) & 6.630341 & $1 \%$ & $* *$ \\
\hline \multicolumn{8}{|c|}{ Test critical values } \\
\hline \multicolumn{5}{|c|}{ I(0) lower bounds } & \multicolumn{3}{|c|}{ I(1) upper bounds } \\
\hline $1 \%$ & $2.5 \%$ & $5 \%$ & $10 \%$ & $1 \%$ & $2.5 \%$ & $5 \%$ & $10 \%$ \\
\hline 4.29 & 3.69 & 3.23 & 2.72 & 5.61 & 4.89 & 4.35 & 3.77 \\
\hline
\end{tabular}

As the above results shows, only when $\mathrm{Y}, \mathrm{P}$ and $\pi$ acts as the dependent variable, the joint significance of the F statistic is larger than the upper bounds, the null of no cointegration hypothesis is rejected. In other words, there is cointegration between the variables.

\subsection{Long run relationship from ARDL model}

Based on the bounds test result ,there are three cointegration relations as follows: 
Table 3: Long-Run Impact of Money Growth on Inflation

\begin{tabular}{|c|c|c|c|c|}
\hline Regressor & Coefficient & $\begin{array}{c}\text { Standard } \\
\text { Error }\end{array}$ & T-Ratio & Prob. \\
\hline $\mathrm{M}$ & 0.349929 & 0.033799 & 10.35327 & 0.0000 \\
\hline $\mathrm{Y}$ & -0.210811 & 0.113246 & -1.861535 & 0.0801 \\
\hline$\pi$ & -1.163744 & 0.137340 & -8.473427 & 0.0000 \\
\hline
\end{tabular}

$$
\begin{array}{lcr}
\mathrm{P}=0.34992851^{*} \mathrm{M} & -0.21081148 * \mathrm{Y} & -1.16374432 * \mathrm{R} \\
\mathrm{Se}(0.033799)^{* * *} & (0.113246) * & (0.137340)^{* * *}
\end{array}
$$

The results show that the positive impact of money supply on inflation rate is statistically significant. This finding is consistent with the theoretical and empirical evidence that money supply is always a monetary phenomenon.

\subsection{Short -run adjustment in ECM}

Table 4: Error correction $\left(\mathrm{ECM}_{t-1}\right)$ coefficient

\begin{tabular}{|c|c|c|c|c|}
\hline Regressor & Coefficient & $\begin{array}{c}\text { Standard } \\
\text { Error }\end{array}$ & T-Ratio & Prob. \\
\hline $\mathrm{D}(\mathrm{P}(-1))$ & 0.345778 & 0.163256 & 2.118012 & 0.0492 \\
\hline $\mathrm{D}(\mathrm{P}(-2))$ & -0.071390 & 0.150220 & -0.475234 & 0.6407 \\
\hline $\mathrm{D}(\mathrm{P}(-3))$ & -0.173287 & 0.128765 & -1.345768 & 0.1961 \\
\hline $\mathrm{D}(\mathrm{M}) * * *$ & 0.071269 & 0.024490 & 2.910087 & 0.0098 \\
\hline $\mathrm{D}(\mathrm{M}(-1))^{* * *}$ & -0.142466 & 0.039607 & -3.597004 & 0.0022 \\
\hline $\mathrm{D}(\mathrm{M}(-2))^{* * *}$ & -0.151884 & 0.032140 & -4.725670 & 0.0002 \\
\hline $\mathrm{D}(\mathrm{M}(-3))^{* * *}$ & -0.097237 & 0.027578 & -3.525858 & 0.0026 \\
\hline $\mathrm{D}(\mathrm{Y})$ & -0.017568 & 0.061499 & -0.285665 & 0.7786 \\
\hline $\mathrm{D}(\mathrm{Y}(-1))^{* * *}$ & 0.235537 & 0.077877 & 3.024483 & 0.0076 \\
\hline $\mathrm{D}(\pi)^{* * *}$ & -1.025384 & 0.057848 & -17.72554 & 0.0000 \\
\hline $\mathrm{D}(\pi(-1))$ & 0.270575 & 0.192203 & 1.407760 & 0.1772 \\
\hline $\mathrm{D}(\pi(-2))$ & -0.122898 & 0.156809 & -0.783744 & 0.4440 \\
\hline $\mathrm{D}(\pi(-3))^{*}$ & -0.261413 & 0.131052 & -1.994724 & 0.0624 \\
\hline $\mathrm{CointEq}(-1)^{* * *}$ & -0.769023 & 0.137674 & -5.585840 & 0.0000 \\
\hline
\end{tabular}

$$
\mathrm{ECM}_{\mathrm{p}}=-0.769023
$$


Next, in order to check the short-run relationship between the variables the ECM is employed. The results of the short-run dynamic coefficients associated with the long-run relationships obtained from the $\mathrm{ECM}_{\mathrm{t}-1}$, represents the error-correction term derived from long-run co-integrating friendship via ARDL model.

The absolute value of the coefficient of error correction term indicates speed of adjustment to restore equilibrium and the negative sign shows convergence in the short-run dynamic model. The coefficient of $\mathrm{ECM}_{t-1}$ in this model is -0.769023 and this means that in each period, about $76.9023 \%$ of shocks can be justified as a longrun trend. The coefficient of $\mathrm{ECM}_{t-1}$ in our model is negative and highly significant. It implies that, in China, money supply, inflation and economic growth are cointegrated when inflation serves as dependent variable.

The error correction coefficient shows, in the short -run adjustment, the adjustment of inflation almost come from money supply

\subsection{Other test}

\subsubsection{Serial Correlation}

Table 5

Breusch-Godfrey Serial Correlation LM Test:

\begin{tabular}{llll}
\hline \hline F-statistic & 0.387646 & Prob. F(4,13) & 0.8137 \\
Obs*R-squared & 3.729777 & Prob. Chi-Square(4) & 0.4438 \\
\hline \hline
\end{tabular}

The result shows the residual of ARDL has no serial correlation

Heteroskedasticity Test

Table 6

Heteroskedasticity Test: Breusch-Pagan-Godfrey

\begin{tabular}{llll}
\hline \hline F-statistic & 1.547260 & Prob. F(17,17) & 0.1885 \\
Obs $^{*}$ R-squared & 21.25974 & Prob. Chi-Square(17) & 0.2149 \\
Scaled explained SS & 3.902889 & Prob. Chi-Square(17) & 0.9996 \\
\hline \hline
\end{tabular}

The result shows that there is no heteroskedasticity. 


\subsubsection{Stability Test}

The long-run stability of the parameters to be estimated is tested applying the cumulative sum (CUSUM) and the cumulative sum of squares (CUSUMSQ) tests.

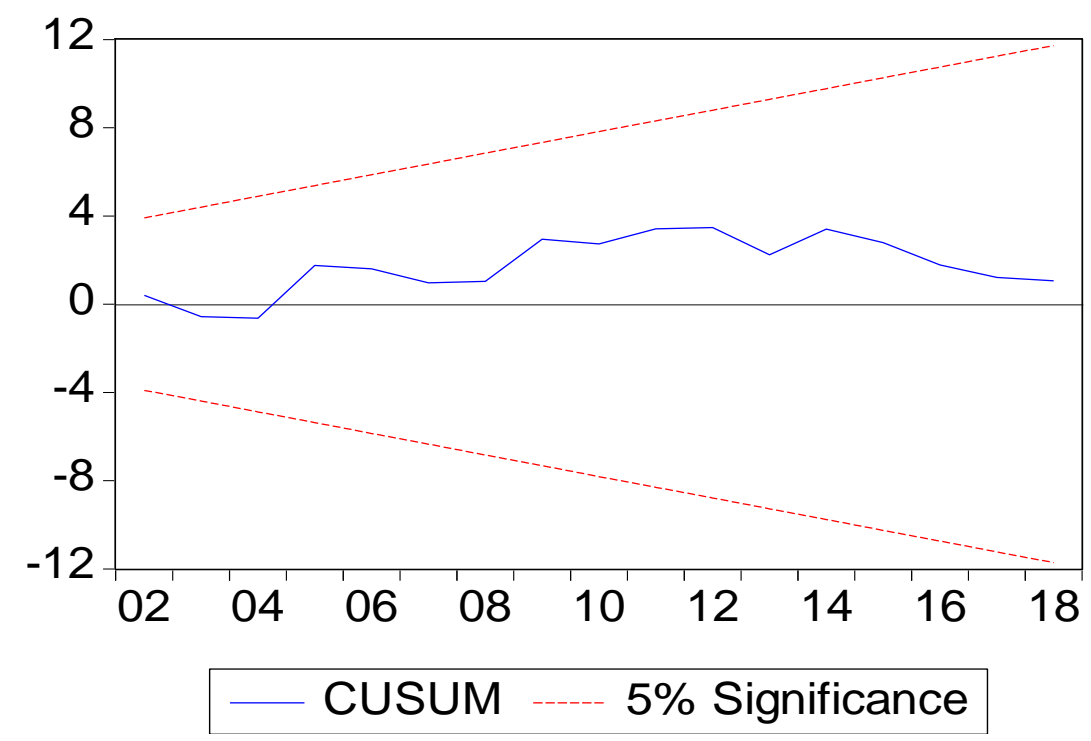

Figure 2

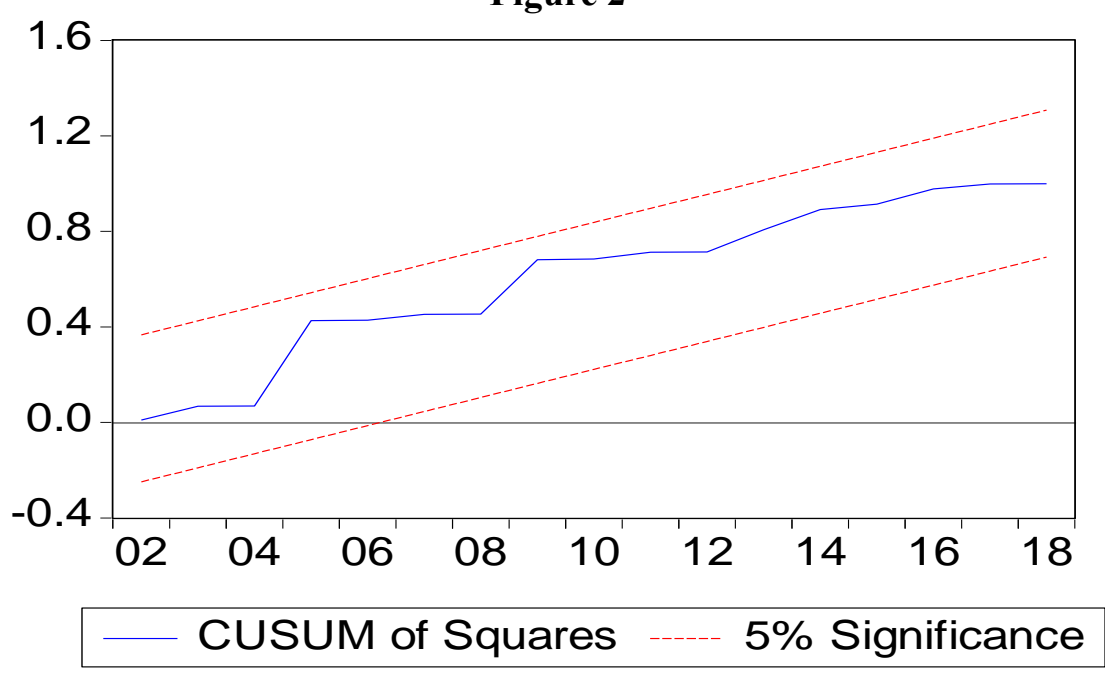

Figure 3

Diagnostic and stability tests confirm that models are econometrically sound and stable. 


\section{Conclusion}

This study aims to use time series data to explore the short-term and long-term effects of money supply on China's inflation rate. The author uses ARDL to estimate the results. An important policy variable is drawn, that is, money supply is the main cause of inflation, and any increase in interest rates can alleviate China's inflationary pressure. The results showed that the increase in national income met people's demand for goods and eased inflationary pressures. This gives economic planners a clear reminder that by controlling interest rates, money supply and national output levels, it may be helpful to control inflation. The results of this research support the view of monetarism and help the government formulate economic policies in a prudent manner to control inflation in China.

\section{References}

[1] Hussain, Muhammad Ijaz, and Tasneem Zafar. "The interrelationship between money supply, inflation, public expenditure and economic growth." European Online Journal of Natural and Social Sciences 7.1 (2018): pp-1.

[2] Pesaran, M. Hashem, Yongcheol Shin, and Richard J. Smith. "Bounds testing approaches to the analysis of level relationships." Journal of applied econometrics 16.3 (2001): 289-326.

[3] Su, Chi-Wei, et al. "Is there causal relationship between money supply growth and inflation in China? Evidence from quantity theory of money." Review of Development Economics 20.3 (2016): 702-719.

[4] Twinoburyo, Enock Nyorekwa, and Nicholas M. Odhiambo. "Monetary policy and economic growth: a review of international literature." Journal of Central Banking Theory and Practice 7.2 (2018): 123-137.

[5] Zhang, Suli. "An Empirical Analysis of the Relationship Between Money Supply and Inflation." Management \& Engineering 32 (2018): 33-38. 